\title{
Association of white cell and red cell antibodies in human sera
}

\author{
JILL M. ROSS ${ }^{1}$ AND D. C. O. JAMES \\ From the Tissue Typing Laboratory, Blood Transfusion Unit, Westminster Hospital, London
}

SYNOPSIS Five hundred and eighteen human sera containing known red cell antibodies were tested for lymphocytotoxic antibodies and 81 sera were found to contain them. Thirty-nine antibodies were fully characterized. The frequencies of anti-I, $\mathrm{K}, \mathrm{V}^{\mathrm{w}}$, and $\mathrm{Wr}^{\mathrm{a}}$ were significantly greater in those of the 518 sera which also contained white cell antibodies.

Four hundred and ninety-four of the 518 sera containing red cell antibodies contained anti-Rh and anti-Kell. The frequency of white cell antibodies in this group was $15 \%$ compared with a frequency of $12 \%$ in a series of 923 antenatal samples not containing anti-Rh or anti-Kell.

The frequencies of different anti-HL-A specificities were compared in the two groups with or without anti-Rh and anti-Kell antibodies. Anti-HL-A 1, 7, and 8 occurred more frequently in the absence of these red cell antibodies and anti-HL-A 12 occurred more frequently in their presence.

No correlation was found between particular red cell and white cell antibodies.

The significance of leuco-platelet (HL-A) antibodies in the serum of parous women is still not clear. Payne (1964) and Jensen (1964) consider them to be harmless, while Moulinier and Mesnier (1969) suggest that they may reinforce the destructive effects of Rhesus antibodies in erythroblastosis foetalis. Harris, MacCaulay, and Wentzel (1970) believe that a 'good antibody producer' might produce abundant Rhesus antibodies together with HL-A antibodies. This would suggest that, in general, a higher incidence of HL-A antibodies might be expected in women who had produced Rhesus or other red cell antibodies. The present study was undertaken to investigate this possibility, and also to see whether there was any correlation between particular red cell and white cell antibodies.

\section{Method}

Five hundred and eighteen sera known to contain red cell antibodies were supplied by the Blood Group Reference Laboratory. All the sera containing red cell antibodies were from sensitized patients, most of whom had been immunized by pregnancy. The parity of the antenatal donors was not known. These

${ }^{1}$ Requests for reprints should be addressed to: Jill M. Ross at Irwin Memorial Blood Bank, 270 Masonic Avenue, San Francisco, California 94118, USA.

Received for publication 14 March 1973. sera containing known red cell antibodies were tested against a cell panel of 50 different lymphocytes which included the following HL-A antigenic phenotypes: first locus HL-A 1, 2, 3, 9, 10, 11, W28; second locus HL-A 5, 7, 8, 12, 13, W5, W10, W15, $\mathrm{W} 22$, and W27. The majority of the sera were also tested against lymphocytes bearing the specificities Da22, Ao28, Da25, W14, and W17 but these were not included when calculating the percentage frequency for each antibody.

A series of 923 antenatal serum samples known not to contain anti-Rh $(\mathrm{C}, \mathrm{D}, \mathrm{E}$, and c) or anti-Kell were obtained from the Westminster Hospital Antenatal Clinic. These were similarly tested for the presence of white cell antibodies.

Lymphocytes were separated by the Ficoll/ Triosil density-gradient technique (Böyum, 1968), the concentration being adjusted to $1 \times 10^{6}$ cells $/ \mathrm{ml}$.

The presence of HL-A antibodies in the sera was detected by a microlymphocytotoxicity technique using plastic Terasaki plates (Terasaki and McClelland, 1964), each plate containing a layer of light liquid paraffin. One $\mu \mathrm{l}$ aliquots of the different sera were dispensed into the wells and the plates stored at $-30^{\circ} \mathrm{C}$. Before use the plates were thawed at $+37^{\circ} \mathrm{C}$. A two-stage technique was used in the lymphocytotoxicity assay. One $\mu l$ of cell suspension was added to $1 \mu \mathrm{l}$ of serum in the Terasaki plate and incubated for 30 minutes at $37^{\circ} \mathrm{C}$. Two $\mu \mathrm{l}$ of rabbit 
complement was then added to each well and the test was incubated for a further 60 minutes. Cell death was shown by the staining of the cells with $5 \%$ aqueous eosin, indicating the presence of a white cell antibody in the serum which is reacting with the HL-A antigen(s) on the cell membrane.

The techniques used by the Blood Group Reference Laboratory for the detection of red cell antibodies were the established techniques described by Dunsford and Bowley (1967). An AutoAnalyzer was not used in any of the work discussed in this paper.

\section{Results}

Eight-one $(15 \%)$ of the 518 sera containing red cell antibodies also contained white cell antibodies. Of these 81 sera, $39(48 \%)$ were found to have antibodies of known specificity. The other $42(52 \%)$ could not be characterized due to weak reactions, multispecificity, or patterns of reactions not definable on our cell panel. The red cell antibodies present in the 518 sera are listed in the table. Predictably, anti-D was the most frequent. Eighty-three percent of the 81 sera containing white cell antibodies contained anti-D compared with $88 \%$ of the other 437 sera without white cell antibodies. The difference between the two is only significant at the $5 \%$ level.

Of the 518 sera containing red cell antibodies, 494 contained anti-Rhesus and anti-Kell. When these were compared with 923 sera not containing anti-Rh or anti-Kell, the frequencies of white cell antibodies were found to be 15 and $12 \%$ respectively. This difference is only significant at the $5 \%$ level but it shows clearly that white cell antibodies are pro-

\begin{tabular}{lc}
\hline Specificity & \multicolumn{1}{c}{$\%$ Frequency } \\
\hline Red Cell & \\
\cline { 2 - 2 } Anti-A & $1 \cdot 2$ \\
Anti A B (immune) & $0 \cdot 2$ \\
Anti H(O) & $0 \cdot 8$ \\
Anti Vw & $2 \cdot 5$ \\
Anti P & $0 \cdot 6$ \\
Anti D & 87 \\
Anti C & 25 \\
Anti E & $9 \cdot 5$ \\
Anti c & $2 \cdot 3$ \\
Anti Lu' & $0 \cdot 2$ \\
Anti K & $1 \cdot 5$ \\
Anti Le & $1 \cdot 6$ \\
Anti Fy & $1 \cdot 6$ \\
Anti Writ & $10 \cdot 6$ \\
Anti I & $3 \cdot 3$ \\
Anti Bg & \\
Serum & $0 \cdot 6$ \\
Anti-Gm & \\
Anti-Inv & $2 \cdot 7$ \\
\hline
\end{tabular}

Table Frequencies of red cell and serum antibodies in 518 human sera

duced even in the absence of the red cell antibodies mentioned above.

The frequencies given in the table are the frequencies of each red cell antibody in the 518 sera. Most of the sera contained more than one red cell antibody.

Figure 1 shows a comparison between the fre- $\frac{2}{0}$ quencies of each white cell antibody in sera with and $\stackrel{\varnothing}{2}$ without Rhesus and Kell antibodies. From this $\overrightarrow{\overrightarrow{0}}$ histogram it can be seen that anti HL-A 12 and to a 3 lesser extent anti HL-A 5 are more frequent in the presence of red cell antibodies, whereas anti HL-A? 1,7 , and 8 are all more frequent when red cello

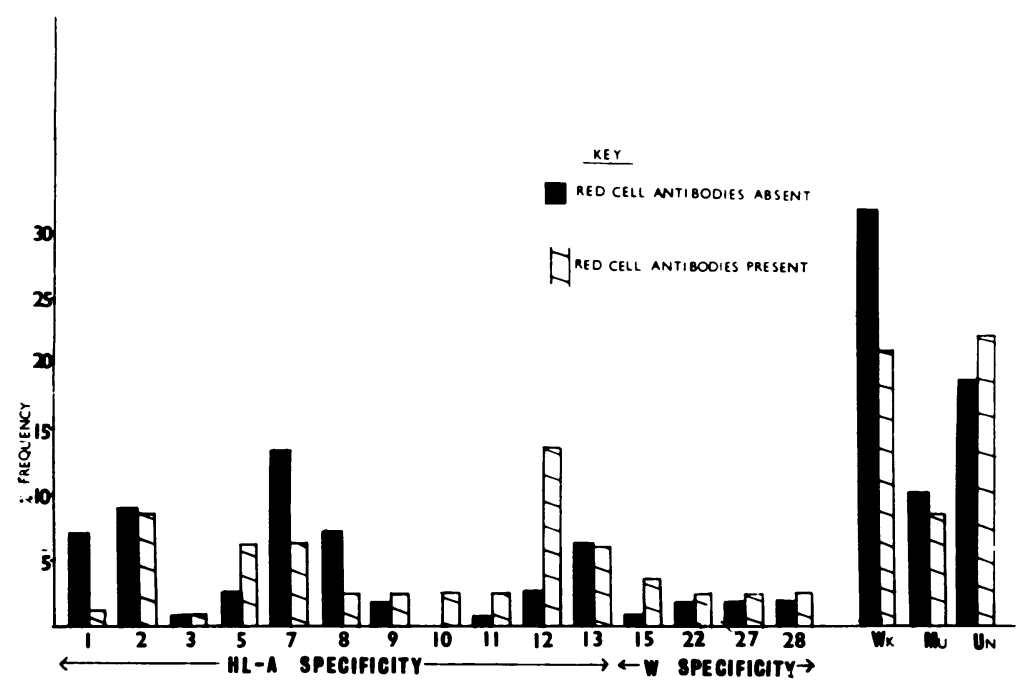

Fig 1 White cell antibodies in the presence and absence of red cell antibodies (anti-Rh and anti-Kell).

$W k=$ weak antibodies

$M u=$ Multispecific antibodies

$U n=$ Antibodies of unidentifiable specificity 
antibodies are not detected. Statistical analysis showed that the differences in frequency of antiHL-A 1,7 , and 12 were significant $(P<0.05)$ while the differences for anti HL-A 5 and HL-A 8 were not $(P>0.05)$. The white cell antibodies included in the histogram are either monospecific or 'functionally specific', and both HL-A and workshop (W) specificities were included.

Figure 2 shows a comparison of the frequencies of each red cell antibody in the sera containing white cell antibodies with the average frequency of the former antibodies in the whole series of 518 sera, ie, with and without white cell antibodies. Anti-I, K, $\mathrm{V}^{\mathrm{w}}$, and $\mathrm{Wr}^{\mathrm{a}}$ are all significantly more frequent when white cell antibodies are present $(P<0.05)$.

A correlation between any particular red cell and white cell antibody could not be shown in this relatively small series.

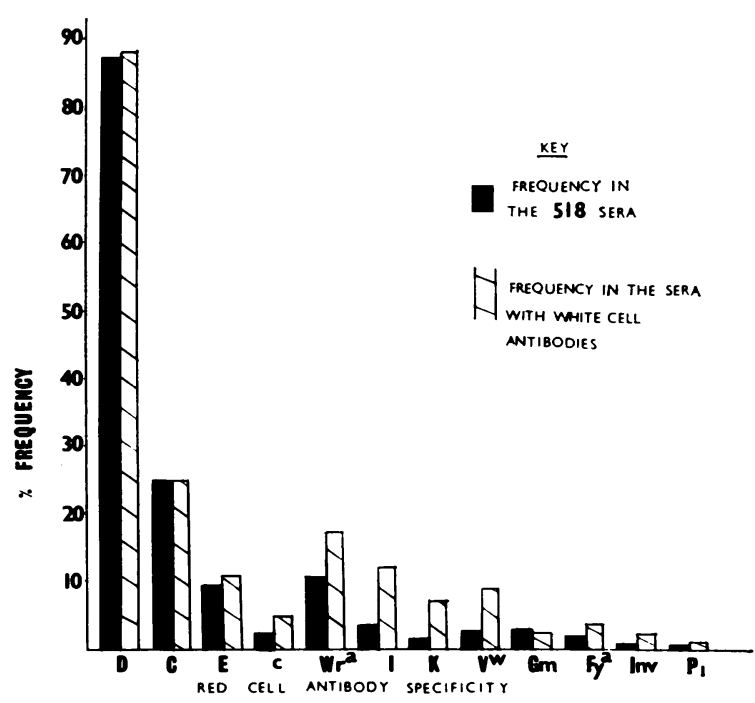

Fig 2 Red cell antibodies in the presence and absence of white cell antibodies.

\section{Discussion}

In this study it was not possible to show any significant correlation between particular white and red cell antibodies. However, Morton, Pickles, and Sutton (1969), using an AutoAnalyzer technique, showed a correlation between anti-Bga and HL-A 7 but the present series did not contain enough examples of anti- $\mathrm{Bg}^{\mathrm{a}}$ to investigate this particular relationship. In this paper they suggested that manual methods are considerably less sensitive than those using the AutoAnalyzer and this may explain, at least partially, our apparent failure to find the correlation indicated above. It was also unfortunate that in our series of 81 sera containing white cell antibodies, only $48 \%$ could be satisfactorily characterized, for technical reasons, in terms of white cell specificity.

It was found that the frequency of white cell antibodies is almost the same in either the presence or absence of red cell antibodies. This does not appear to support the idea of a 'good antibody producer' as suggested by Harris et al (1970). In fact, our findings would indicate that red and white cell antibodies may be produced by independent mechanisms. Several studies undertaken to investigate the occurrence of leucocyte antibodies in primiparous women show that it is quite possible for these to be formed during or just after a first pregnancy (Jensen, 1962; Overweg and Engelfriet, 1969; Tongio, Berrebi, Pfeiffer, and Mayer, 1971). Except for immune anti-A and anti-B, it is uncommon for red cell antibodies to be demonstrable at this stage.

This is particularly interesting since the blood groups $\mathbf{A}$ and $\mathbf{B}$ are known to be very important histocompatibility antigens.

The increased incidence of anti-I, $K, V^{w}$, and $\mathrm{Wr}^{\mathrm{a}}$ in the presence of white cell antibodies is also of some interest. This may reflect some relationship between these particular red cell and white cell antigens.

It should be noted that in our series no data were available regarding the $\mathrm{ABO}$ groupings and HL-A typings of the donors from whom the antenatal sera under investigation were obtained. Neither had we any such data regarding the husbands or child (ren). With these data a more accurate picture could have been obtained since any potential immunization, ie, antibody production, would have been predictable. A further guide as to whether a mother is likely to be immunized by foetal leucocytes would be their detection in the mother's blood. However, at the present time there is no convenient method of distinguishing between foetal and maternal leucocytes (Ahrons, 1971).

Finally, this investigation may not have shown a correlation between particular red cell and white cell antibodies because of the relatively small numbers available for final analysis. We believe that in a larger series the expected correlations might well be found, especially in view of the more recent work of Morton, Pickles, Sutton, and Skov (1971). The collection of the several hundred sera containing both red and white cell antibodies which we believe to be necessary could best be achieved by a blood transfusion or other centre having access to a large number of antenatal sera. 
We are particularly grateful to Dr K. L. G. Goldsmith, Director, Blood Group Reference Laboratory, London, for providing sera with known red cell antibodies and for the associated data. We also thank Dr H. Festenstein (London Hospital) and Dr J. Ray (NIH, Bethesda, USA) for contributions of tissue typing antisera, Dr J. Sachs for advice in preparing this paper for publication, and Miss Lee Hummelen for skilled technical assistance. The investigation was supported by a grant from the Governors' Discretionary Fund, Westminster Hospital.

\section{References}

Ahrons, S. (1971). Leukocyte antibodies: occurrence in primigravidae. Tissue Antigens, 1, 178-183.

Böyum, A. (1968). Isolation of leucocytes from human blood: further observations. Scand. J. clin. Lab. Invest., 21, Suppl., 97, 31-50.

Dunsford, I., and Bowley, C. C. (1967). Techniques in Blood Grouping. Oliver and Boyd, Edinburgh.
Harris, R., MacCaulay, M. B., and Wentzel, J. (1970). Prevention of leucocyte antibody formation. Lancet, 1, 544-546.

Jensen, K. G. (1962). Leucocyte antibodies in serums of pregnant women: serology and clinic. Vox Sang. (Basel), 7, 454-469.

Jensen, K. G. (1964). Leucocyte antibodies in serums of pregnant women: serology and clinic. II. Vox Sang. (Basel), 9, 315-332.

Morton, J. A., Pickles, M. M., and Sutton, L. (1969). The correlation 흠 of the Bg $^{\mathrm{a}}$ blood group with the HL-A7 leucocyte group. $\overline{\bar{\omega}}$ Demonstration of antigenic sites on red cells and leucocytes. $\vec{\nabla}$ Vox Sang. (Basel), 17, 536-547.

Morton, J. A., Pickles, M. M., Sutton, L., and Skov, F. (1971). Identification of further antigens on red cells and lymphocytes. क Vox Sang. (Basel), 21, 141-153.

Moulinier, J., and Mesnier, F. (1969). Paper read at the 12th International Conference on Blood Transfusion, Moscow (in the press). $\overrightarrow{\vec{J}}$

Overweg, J., and Engelfriet, C. P. (1969). Cytotoxic leucocyte isoantibodies formed during the first pregnancy. Vox Sang. (Basel), $16,97-104$.

Payne, R. (1964). Neonatal neutropenia and leucoagglutinins. Pediatrics, 33, 194-204.

Terasaki, P. I., and McClelland, J. D. (1964). Microdroplet assay of Cr human serum cytotoxins. Nature (Lond.), 204, 998-1000.

Tongio, M. M., Berrebi, A., Pfeiffer, B., and Mayer, S. (1971). Serological studies on lymphocytoxic antibodies in primiparous 0 women. Tissue Antigens, 1, 243-257. 